\title{
Implementation of Complex Proportional Assessment Method in the Selection of Mango Seeds
}

\author{
Mesran1, Putri Ramadhani², Adriansyah Nasution'3, Dodi Siregar4, Fadlina5, \\ Andysah Putera Utama Siahaan ${ }^{6}$ \\ ${ }^{1,2,3}$ Department of Computer Informatics, STMIK Budi Darma, Indonesia \\ ${ }^{4}$ Department of Informatics, Sekolah Tinggi Teknik Harapan, Medan, Indonesia \\ ${ }^{5}$ Departement of Informatics Management, AMIK STIEKOM Sumatera Utara, Indonesia \\ ${ }^{6}$ Faculty of Computer Science, Universitas Pembangunan Panca Budi, Medan, Indonesia \\ ${ }^{6}$ School of Computer and Communication Engineering, Universiti Malaysia Perlis, Kangar, Malaysia
}

\begin{abstract}
Mango is a high-level plant species with woody stems having a height of 10-40 m. Mango fruit in consumption because it tastes sweet and has a high fiber content. In selecting good mango seedlings, it needs the appropriate criteria to pick the best seeds, so that farmers are not wrong in cultivating mango tree seedlings. Complex Proportional Assessment (COPRAS) method is the best technique to determine the mango seeds, by providing positive and negative criteria.
\end{abstract}

Keywords: Mango, COPRAS Method, DSS

\section{INTRODUCTION}

Superior seed is the main requirement for the development of a plant, how to obtain these superior seeds can be done by vegetative propagation such as grafting, grafting, and arrangement. One of the plants that are loved by the community is mango plants, to get superior mango seedlings required some election process done manually. This process sometimes does not result in an appropriate decision because it is done manually that the workmanship takes much time and the tendency of many mistakes caused by human limitations. Every commodity has its character regarding seed propagation. In ambarella fruit, propagation of good seeds is using young entres, while the durian using young entres with temple eyes are not woody.

Mango (Mangifera indica L) is a perennial crop (perennial). Mango is a plant originating from India then spread to Southeast Asia including Indonesia. Mango plants belong to the Anacardiaceae family. Mangoes include high-level plants, woody stems that have a height of 10 - 40 m. Many mangoes are consumed after being cooked because it tastes sweet. Mango fruit is a very useful source of fiber for digestion in the human body. Also can be, consumed as fresh fruit, mango can also be processed into various foods and beverages such as mango syrup, mango juice, mango pudding and canned fruit.

Along with the rapid development of technology, the need for information is essential, especially information that produces contain the correct value, accurate, fast, and precise. It requires a system that can determine the best mango tree seedlings and to get tree seedlings the best mango; then Decision Support System is believed to be able to facilitate in determining the best mango tree seeds.

Decision Support System is a system that can provide problem-solving capabilities and alternative capabilities for problems with both structured and unstructured conditions. This system was created to make decisions in all abstract decision situations. This technique aims to provide information, guide, provide predictions and direct users to make better decisions [1][2][12][13].

In this application the system uses methods to perform decision analysis, such as Complex Proportional Assessment (COPRAS), Weighted Sum Model (WSM), Weighted Product Model (WPM), Visekriterijumska Optimizacija I Kompromisno Resenje (VIKOR), Analytic Hierarchy Process (AHP), Elimination and 
Choice Translation Reality (ELECTRE), Simple MultiAttribute Rating Technique (SMART) [3][4][5].

In the previous study conducted in STMIK Budi Darma Medan, in this case, choosing the best lecturer by using Elimination and Choice Translation Reality (ELECTRE) to improve the lecturer motivation so that the measurement of Lecturer Performance Index become more increase [6]. From the above explanation, the authors chose the COPRAS method because of this multicriteria decision-making method using gradual ranking and evaluate the alternative procedure regarding significance and degree utility; COPRAS method is very efficient that can be used in the selection of the best seedlings[7][8].

\section{METHODS AND MATERIAL}

\subsection{Decision Support System}

DSS (Decision Support System) is an interactive information system assisting decision makers in providing information, modeling, and manipulation of data[9][10][11].

DSS (Decision Support System) is a tool for decision makers in expanding their capabilities, but not to replace the assessment. DSS (Decision Support System) is intended for decisions that require assessment or on decisions that algorithms can not support[10].

\subsection{Mango}

Mango (Mangifera indica) is the name of fruits and the name of the tree belonging to the clan Mangifera and Anacardiaceae tribe that has about 35-40 members. Mango plants and fruit Come from around the Indian border with Burma. Mango trees include high-level plants whose stem structure (habitus) belongs to the Arboretum group, i.e., woody plants having a stem height greater than $5 \mathrm{~m}$. Mango can reach a height of 10$40 \mathrm{~m}$.

\subsection{Complex Proportional Assessment (COPRAS)}

The COPRAS method assumes the direct and proportional dependence of the level of significance and utility of the alternatives, in the presence of conflicting criteria. It takes into account alternative performance concerning different criteria as well as corresponding criteria weightings. This method selects the best decision considering an ideal and ideal-worst solution.

In this study, the application of COPRAS is used to evaluate Mango tree seedlings by the criteria set. It is useful to produce the best seeds that will be marketed to Mango Farmers. The use of COPRAS on decision support takes into account the positive (favorable) and negative (unfavorable) criteria, which are valued separately to process a decision[8].

This is the steps of COPRAS method[8][7]:

Step 1: Prepare the decision matrix.

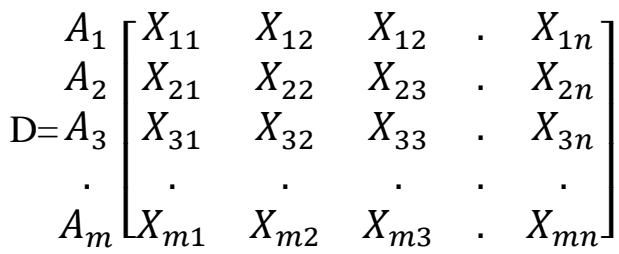

Step 2: Normalize decision-making matrix. To normalize the decision matrix using the following formula.

$$
X_{i j}=\frac{X_{i j}}{\sum_{1=1}^{m} X_{i j}}
$$

Step 3: Determine a normalized weighted decisionmaking matrix.

$$
\mathrm{D}^{\prime}=d_{i j}=X_{i j} * . W_{j}
$$

Step 4: Calculation maximizes and minimizes index for each alternative.

In this phase, each alternative is categorized as maximizing and minimizing indexes by formulas (4) and (5).

$$
\begin{aligned}
& S_{i+}=\sum_{j=1}^{k} d_{i j} \quad j=1,2, \ldots \ldots \ldots, k \\
& S_{i-}=\sum_{j=1}^{k} d_{i j} j=k+1, k+2 \ldots, n
\end{aligned}
$$

Step 5: Calculate the relative weights of each alternative. The relative weights $Q_{i}$ of alternative i, are calculated as follows. 
$Q_{i}=\mathrm{S}_{+\mathrm{i}}+\frac{\min \mathrm{S}_{-\mathrm{i}} \sum_{\mathrm{i}=1}^{\mathrm{m}} \mathrm{s}_{-\mathrm{i}}}{\min \mathrm{S}_{-\mathrm{i}} \sum_{\mathrm{i}=1}^{\mathrm{m}} \mathrm{S}_{-\mathrm{i}}}$

Step 6: Determine alternative positional order. Alternative priority sequences are compared based on their relative weights. An alternative with a relatively higher weight priority (rank) and an alternative with a relatively higher weight is the most acceptable alternative.

$$
A^{*}=\left\{A_{i} \mid \max Q_{i}\right\}
$$

Step 7: Calculate the Performance Index (Pi) of each value for an alternative. In the last section, the formula $\mathrm{Pi}$ is calculated by the following formula.

$P_{i}=\frac{Q_{i}}{Q_{\max }} \cdot 100 \%$

The best alternative is an alternative that has a value of one hundred (100) percent.

\section{RESULTS AND DISCUSSION}

COPRAS Method in the process required criteria that will be used as a calculation material on the process of the rank type of best mango seeds. Criteria to be considered are as follows.

Table 1. Criteria and Weight

\begin{tabular}{|l|c|c|}
\hline \multicolumn{1}{|c|}{ Criteria } & Weight & Type \\
\hline Stem Diameter (C1) & 0.20 & Benefit \\
\hline Leaf Section (C2) & 0.20 & Benefit \\
\hline Plant High (C3) & 0.10 & Benefit \\
\hline Physical Condition (C4) & 0.40 & Benefit \\
\hline Number of Branches (C5) & 0.1 & Cost \\
\hline
\end{tabular}

Table 2 is an alternative to mango tree seedlings.

Table 2. The Alternative of Mango

\begin{tabular}{|c|c|c|c|c|c|}
\hline Alternative & $\mathrm{C} 1$ & $\mathrm{C} 2$ & C3 & C4 & C5 \\
\hline $\begin{array}{c}\text { A1- } \\
\text { Arummanis } 01\end{array}$ & $\begin{array}{l}1.5 \\
\mathrm{~cm}\end{array}$ & $\begin{array}{c}3 \\
\text { sheet }\end{array}$ & $\begin{array}{l}15 \\
\mathrm{~cm}\end{array}$ & $\begin{array}{l}\text { Healthy } \\
\text { Visual }\end{array}$ & 2 \\
\hline $\begin{array}{c}\text { A2- } \\
\text { Arummanis } 02\end{array}$ & $\begin{array}{l}1.7 \\
\mathrm{~cm}\end{array}$ & $\begin{array}{c}4 \\
\text { sheet }\end{array}$ & $\begin{array}{l}15 \\
\mathrm{~cm}\end{array}$ & $\begin{array}{c}\text { Healthy } \\
\text { visual }\end{array}$ & 3 \\
\hline $\begin{array}{c}\text { A3- } \\
\text { Arummanis } 03\end{array}$ & $\begin{array}{l}1.2 \\
\mathrm{~cm}\end{array}$ & $\begin{array}{c}3 \\
\text { sheet }\end{array}$ & $5 \mathrm{~cm}$ & $\begin{array}{c}\text { Visually } \\
\text { Damaged }\end{array}$ & 1 \\
\hline $\begin{array}{c}\text { A4- } \\
\text { Arummanis } 04\end{array}$ & $\begin{array}{c}1 \\
\mathrm{~cm}\end{array}$ & $\begin{array}{c}2 \\
\text { sheet }\end{array}$ & $\begin{array}{l}10 \\
\mathrm{~cm}\end{array}$ & $\begin{array}{l}\text { Visually } \\
\text { Damaged }\end{array}$ & 2 \\
\hline $\begin{array}{c}\text { A5- } \\
\text { Arummanis } 05\end{array}$ & $\begin{array}{c}2 \\
\mathrm{~cm}\end{array}$ & $\begin{array}{c}6 \\
\text { sheet }\end{array}$ & $\begin{array}{l}25 \\
\mathrm{~cm}\end{array}$ & $\begin{array}{c}\text { Healthy } \\
\text { Visual }\end{array}$ & 1 \\
\hline
\end{tabular}

The weighting for each criterion is determined by the importance of each criterion. The highest importance level is in the stem diameter and leaf criteria, then the plant height criteria and physical condition criteria have a second and equal importance level. Based on the weighted value of the importance of each criterion, the initial weight for each criterion ( $\mathrm{C} 1$ - C5) of each alternative can be seen in the following tables:

Table 3 is the value range of the Stem Diameter criteria.

Tabel 3. The Value of Stem Diameter (C1)

\begin{tabular}{|c|c|}
\hline Information & Value \\
\hline $1 \mathrm{~cm}-1.4 \mathrm{~cm}$ & 3 \\
\hline $1.5 \mathrm{~cm}-1.9 \mathrm{~cm}$ & 4 \\
\hline $2 \mathrm{~cm}$ & 5 \\
\hline
\end{tabular}

Table 4 shows the range of values of the Leaf Section criteria.

Table 4. Criteria for Leaf Section (C2)

\begin{tabular}{|c|c|}
\hline Information & Value \\
\hline 1 sheet -2 sheet & 2 \\
\hline 3 sheet -4 sheet & 4 \\
\hline 5 sheet -6 sheet & 5 \\
\hline
\end{tabular}

Table 5 is a range of values from Plant High.

Table 5. Plant High (C3)

\begin{tabular}{|c|c|}
\hline Information & Value \\
\hline $1 \mathrm{~cm}-9 \mathrm{~cm}$ & 1 \\
\hline $10 \mathrm{~cm}-15 \mathrm{~cm}$ & 3 \\
\hline $16 \mathrm{~cm}-19 \mathrm{~cm}$ & 4 \\
\hline $20 \mathrm{~cm}-25 \mathrm{~cm}$ & 5 \\
\hline
\end{tabular}

Table 6 is a range of values from Physical Condition.

Table 6. Physical Condition (C4)

\begin{tabular}{|c|c|}
\hline Information & Value \\
\hline Healthy Visual & 5 \\
\hline Visually Damaged & 1 \\
\hline
\end{tabular}

Table 7 is a range of values from Physical Condition.

Table 7. Number of Branch (C5)

\begin{tabular}{|c|c|}
\hline Information & Value \\
\hline $1-2$ & 5 \\
\hline $3-4$ & 1 \\
\hline
\end{tabular}


Based on table $\mathrm{V}$ and the range of values on each criterion, the results of each alternative are obtained as follows:

Table 8 is a list of Mango Tree alternatives to be selected the best with the range of table III - VII criteria.

Table 8. Mango Tree Alternative

\begin{tabular}{|c|c|c|c|c|c|}
\hline Alternative & C1 & C2 & C3 & C4 & C5 \\
\hline $\mathrm{A}_{1}$ & 4 & 4 & 3 & 5 & 5 \\
\hline $\mathrm{A}_{2}$ & 4 & 4 & 3 & 5 & 1 \\
\hline $\mathrm{A}_{3}$ & 3 & 4 & 1 & 1 & 5 \\
\hline $\mathrm{A}_{4}$ & 3 & 2 & 3 & 1 & 5 \\
\hline $\mathrm{A}_{5}$ & 5 & 5 & 5 & 5 & 5 \\
\hline
\end{tabular}

In determining the best mango tree alternative use the following COPRAS calculation steps:

Based on equation 1 determine the decision matrix.

$X=\left[\begin{array}{llll}4 & 4 & 3 & 5 \\ 4 & 4 & 3 & 5 \\ 3 & 4 & 1 & 1 \\ 3 & 2 & 3 & 1 \\ 5 & 5 & 5 & 5\end{array}\right]$

Then calculate the normalized matrix

$$
\begin{gathered}
\mathrm{C} 1=(4+4+3+3+5)=19 \\
\mathrm{~A}_{11}=4: 19=0.21 \\
\mathrm{~A}_{21}=4: 19=0.21 \\
\mathrm{~A}_{31}=3: 19=0.16 \\
\mathrm{~A}_{41}=3: 19=0.16 \\
\mathrm{~A}_{51}=5: 19=0.26
\end{gathered}
$$

$\mathrm{C} 2=(4+4+4+2+5)=19$

$\mathrm{A}_{12}=4: 19=0.21$

$\mathrm{A}_{22}=4: 19=0.21$

$\mathrm{A}_{32}=4: 19=0.21$

$\mathrm{A}_{42}=2: 19=0.11$

$\mathrm{A}_{52}=5: 19=0.26$

$$
\begin{aligned}
\mathrm{C} 3=(3 & +3+1+3+5)=15 \\
\mathrm{~A}_{13} & =3: 15=0.20 \\
\mathrm{~A}_{23} & =3: 15=0.20 \\
\mathrm{~A}_{33} & =1: 15=0.07 \\
\mathrm{~A}_{43} & =3: 15=0.20 \\
\mathrm{~A}_{53} & =5: 15=0.33
\end{aligned}
$$

$$
\begin{gathered}
\mathrm{C} 4=(5+5+1+1+5)=17 \\
\mathrm{~A}_{14}=5: 17=0.29 \\
\mathrm{~A}_{24}=5: 17=0.29 \\
\mathrm{~A}_{34}=1: 17=0.06
\end{gathered}
$$

$\mathrm{A}_{44}=1: 17=0.06$

$\mathrm{A}_{55}=5: 17=0.29$

$$
\begin{gathered}
\mathrm{C} 5=(5+1+5+5+5)=21 \\
\mathrm{~A}_{15}=5: 21=0.24 \\
\mathrm{~A}_{25}=1: 21=0.05 \\
\mathrm{~A}_{35}=5: 21=0.24 \\
\mathrm{~A}_{45}=5: 21=0.24 \\
\mathrm{~A}_{55}=5: 21=0.24
\end{gathered}
$$

From the calculation obtained matrix Xij

$$
X i j=\left[\begin{array}{lllll}
0.21 & 0.21 & 0.20 & 0.29 & 0.24 \\
0.21 & 0.21 & 0.20 & 0.29 & 0.05 \\
0.16 & 0.21 & 0.07 & 0.06 & 0.24 \\
0.16 & 0.11 & 0.20 & 0.06 & 0.24 \\
0.26 & 0.26 & 0.33 & 0.29 & 0.24
\end{array}\right]
$$

The next stage determines the weighted decision-making matrix using equation 3 .

$\mathrm{A}_{11}=0.21 * 0.2=0.0421$
$\mathrm{~A}_{21}=0.21 * 0.2=0.0421$
$\mathrm{~A}_{31}=0.15 * 0.2=0.0315$
$\mathrm{~A}_{41}=0.15 * 0.2=0.0315$
$\mathrm{~A}_{51}=0.26 * 0.2=0.0526$

$\mathrm{A}_{12}=0.21 * 0.2=0.0421$

$\mathrm{A}_{22}=0.21 * 0.2=0.0421$

$\mathrm{A}_{32}=0.21 * 0.2=0.0421$

$\mathrm{A}_{42}=0.10 * 0.2=0.0210$

$\mathrm{A}_{52}=0.26 * 0.2=0.0526$

$\mathrm{A}_{13}=0.02 * 0.1=0.02$

$\mathrm{A}_{23}=0.02 * 0.1=0.02$

$\mathrm{A}_{33}=0.006 * 0.1=0.006$

$\mathrm{A}_{43}=0.02 * 0.1=0.02$

$\mathrm{A}_{53}=0.03 * 0.1=0.03$

$\mathrm{A}_{14}=0.29 * 0.4=0.117$

$\mathrm{A}_{24}=0.29 * 0.4=0.117$

$\mathrm{A}_{34}=0.05 * 0.4=0.023$

$\mathrm{A}_{44}=0.05 * 0.4=0.023$

$\mathrm{A}_{54}=0.29 * 0.4=0.0117$

$\mathrm{A}_{15}=0.23 * 0.1=0.23$

$\mathrm{A}_{25}=0.04 * 0.1=0.04$

$\mathrm{A}_{35}=0.23 * 0.1=0.023$

$\mathrm{A}_{45}=0.23 * 0.1=0.023$

$\mathrm{A}_{55}=0.23 * 0.1=0.023$

Then the matrix $D_{i j}$ : 
$D i j=\left[\begin{array}{lllll}0.042 & 0.042 & 0.020 & 0.118 & 0.024 \\ 0.042 & 0.042 & 0.020 & 0.118 & 0.005 \\ 0.032 & 0.042 & 0.007 & 0.024 & 0.024 \\ 0.032 & 0.021 & 0.020 & 0.024 & 0.024 \\ 0.053 & 0.053 & 0.033 & 0.118 & 0.024\end{array}\right]$

Next, calculate the value of benefit (equation 4) and cost (equation 5) index for each alternative.
$\mathrm{A}_{1}=0.042+0.042+0.020+0.118=0.222$
$\mathrm{A}^{2}=0.042+0.042+0.020+0.118=0.222$
$\mathrm{A}_{3}=0.032+0.042+0.007+0.024=0.104$
$\mathrm{A}_{4}=0.032+0.021+0.020+0.024=0.096$
$\mathrm{A}_{5}=0.053+0.053+0.033+0.118=0.256$

Calculation of minimizes S- (C5)
$\mathrm{A}_{1}=0.0238$
$\mathrm{A}^{2}=0.0048$
$\mathrm{A}_{3}=0.0238$
$\mathrm{A}_{4}=0.0238$
$\mathrm{A}_{5}=0.0238$

The total of the Cost attribute, is : 0.100

Table 9 is a calculation of the relative weights of each alternative.

Table 9. Calculation of the relative weights of each alternative

\begin{tabular}{|c|c|}
\hline $1 /$ S- $\mathrm{i}$ & S- $*$ Total $(1 / \mathrm{S}-\mathrm{i})$ \\
\hline 42 & $0.0238 * 378=9$ \\
\hline 210 & $0.0048 * 378=1.8$ \\
\hline 42 & $0.0238 * 378=9$ \\
\hline 42 & $0.0238 * 378=9$ \\
\hline 42 & $0.0238 * 378=9$ \\
\hline Total $=378$ & \\
& \\
\hline
\end{tabular}

Specify an alternate priority sequence

$\begin{array}{ll}\mathrm{Q}_{1}=0.2219+(0.1 / 9) & =0.23 \\ \mathrm{Q}_{2}=0.2219+(0.1 / 1.8) & =0.28 \\ \mathrm{Q}_{3}=0.1039+(0.1 / 9) & =0.11 \\ \mathrm{Q}_{4}=0.0962+(0.1 / 9) & =0.11 \\ \mathrm{Q}_{5}=0.2562+(0.1 / 9) & =0.27\end{array}$

$\operatorname{Max}\left(Q_{i}\right)=0.28$

Calculation of Performance Index (Pi) value for each alternative
$\mathrm{P}_{1}=(0.23 / 0.28) * 100=80.98 \%$
$\mathrm{P}_{2}=(0.28 / 0.28) * 100=100.0 \%$
$\mathrm{P}_{3}=(0.11 / 0.28) * 100=41.45 \%$
$\mathrm{P}_{4}=(0.11 / 0.28) * 100=38.67 \%$
$\mathrm{P}_{5}=(0.27 / 0.28) * 100=96.37 \%$

Table 10. Results of COPRAS

\begin{tabular}{|c|l|c|}
\hline Alternative & \multicolumn{1}{|c|}{$\mathrm{P}_{\mathrm{i}}$} & Rank \\
\hline $\mathrm{A}_{1}$ & 80.98 & 3 \\
\hline $\mathrm{A}_{2}$ & 100 & 1 \\
\hline $\mathrm{A}_{3}$ & 41.45 & 4 \\
\hline $\mathrm{A}_{4}$ & 38.67 & 5 \\
\hline $\mathrm{A}_{5}$ & 96.37 & 2 \\
\hline
\end{tabular}

From the above alternative calculations then the A5 mango seeds $\mathrm{A}_{2}$-Arummanis was selected as the best mango seeds.

\section{IV.CONCLUSION}

Discussion of the above research can be concluded:

1. Implementation of decision support system by applying Complex Proportional Assessment (COPRAS) method although simple but able to solve problems well in a selection of mango tree seedlings.

2. Decision makers are able to make better decisions more effectively.

3. The results obtained from the calculation of this system only as a tool for decision makers the selection of the best mango tree seedlings.

\section{REFERENCES}

[1]. Khairul;, M. Simaremare, A. Putera, and U. Siahaan, "Decision Support System in Selecting The Appropriate Laptop Using Simple Additive Weighting," Int. J. Recent TRENDS Eng. Res., vol. 2, no. 12, pp. 215-222, 2016.

[2]. Fadlina, L. T. Sianturi, A. Karim, and A. P. U. Siahaan, "Best Student Selection Using Extended Promethee II Method," Int. J. Recent Trends Eng. Res., vol. 3, no. 8, pp. 21-29, 2017.

[3]. Mesran, K. Tampubolon, R. D. Sianturi, F. T. Waruwu, and A. P. U. Siahaan, "Determination of Education Scholarship Recipients Using Preference Selection Index," Int. J. Sci. Res. Sci. Technol., vol. 3, no. 6, pp. 230-234, 2017.

[4]. Risawandi and R. Rahim, "Study of the Simple Multi-Attribute Rating Technique For Decision 
Support," IJSRST, vol. 2, no. 6, pp. 491-494, 2016.

[5]. Jasri, D. Siregar, and R. Rahim, "Decision Support System Best Employee Assessments with Technique for Order of Preference by Similarity to Ideal Solution," Int. J. Recent TRENDS Eng. Res., vol. 3, no. 3, pp. 6-17, 2017.

[6]. Mesran, G. Ginting, Suginam, and R. Rahim, "Implementation of Elimination and Choice Expressing Reality ( ELECTRE ) Method in Selecting the Best Lecturer ( Case Study STMIK BUDI DARMA )," Int. J. Eng. Res. Technol. (IJERT, vol. 6, no. 2, pp. 141-144, 2017.

[7]. E. Y. Ress., "Performance Evaluation Of Research Assistants By Copras Method," Eur. Sci. J., pp. 102-109, 2016.

[8]. P. Chatterjee, "Gear Material Selection using Complex Proportional Assessment and Additive Ratio Assessment-based Approaches: A Comparative Study," Int. J. Mater. Sci. Eng., vol. 1, no. 2, pp. 104-111, 2013.

[9]. S. Kusumadewi, S. Hartati, A. Harjoko, and R. Wardoyo, Fuzzy Multi-Attribute Decision Making (Fuzzy MADM). Yogyakarta: Graha Ilmu, 2006.

[10]. T.-P. Turban, E., Aronson, J., \& Liang, Decision Support Systems And Inteligence System. US: Prentice-Hall, 2005.

[11]. Hasibuan, H.A., Purba, R.B., and Siahaan, A.P.U.: 'Productivity Assessment (Performance, Motivation, and Job Training) using Profile Matching', International Journal of Economics and Management Studies, 2016, 3, (6), pp. 73-77

[12]. Perangin-angin, M.I., Fitriani, W., Mayasari, N., and Siahaan, A.P.U.: 'Tuition Reduction Determination Using Fuzzy Tsukamoto', International Journal of Engineering Science Invention, 2016, 5, (9), pp. 68-72

[13]. Siahaan, A.P.U.: 'Fuzzification of College Adviser Proficiency Based on Specific Knowledge', International Journal of Advanced Research in Computer Science and Software Engineering, 2016, 6, (7), pp. 164-168 